\title{
Preparation of sialon-transition metal silicide composites
}

\author{
Wei-Wu Chen ${ }^{\mathrm{a}, \mathrm{b}}$, Yi-Bing Cheng ${ }^{\mathrm{b}, *}$, Wei-Hsing Tuan ${ }^{\mathrm{c}}$ \\ ${ }^{a}$ Shanghai Institute of Ceramics, CAS, Shanghai 200050, PR China \\ ${ }^{\mathrm{b}}$ School of Physics and Materials Engineering, Monash University, Clayton, Vic. 3800, Australia \\ ${ }^{\mathrm{c}}$ Department of Materials Science and Engineering, National Taiwan University, Taipei, Taiwan
}

Received 20 February 2003; received in revised form 28 September 2004; accepted 3 October 2004

Available online 8 December 2004

\begin{abstract}
A process to prepare sialon-transition metal silicide composites is proposed in the present study. The oxides of transition metals are used as the starting materials and the metal silicides are formed in situ in sialons at elevated temperature. The metal oxides, silica and alumina in starting materials first form a liquid phase on sintering to assist the densification in the graphite furnace. The transition metals then precipitate out to react with $\mathrm{Si}_{3} \mathrm{~N}_{4}$ to form silicides. The sialon-metal silicide composites with uniform microstructures can be produced. By applying a suitable post-sintering heat-treatment, metallic fibers can also be formed in situ in the surface region on samples. Results for both sialon-Cr-silicide and sialon-Fe-silicide composites are demonstrated in the present study.
\end{abstract}

(C) 2004 Elsevier Ltd. All rights reserved.

Keywords: Sialon; Silicide; Composite; Processing

\section{Introduction}

Sialon belongs to the family of silicon nitride based ceramics and is a typical structural material. ${ }^{1-3}$ There are two major forms of sialons, namely $\alpha$-sialon $\left(\alpha^{\prime}\right.$, $\left.\mathrm{Ln}_{x} \mathrm{Si}_{12-(m+n)} \mathrm{Al}_{m+n} \mathrm{O}_{n} \mathrm{~N}_{16-n}\right)$ and $\beta$-sialon $\left(\beta^{\prime}, \mathrm{Si}_{6-z} \mathrm{Al}_{z}\right.$ $\mathrm{O}_{z} \mathrm{~N}_{6-z}$ ). Both sialon phases are derived from the parent silicon nitride $\left(\mathrm{Si}_{3} \mathrm{~N}_{4}\right)$ with partial substitutions of $\mathrm{Al}-\mathrm{O}$ and $\mathrm{Al}-\mathrm{N}$ bonds for $\mathrm{Si}-\mathrm{N}$ bonds. The $\alpha$-sialon is stabilized by trapping "modifying" cations such as $\mathrm{Li}, \mathrm{Ca}, \mathrm{Y}$ and selected rare-earth elements in the interstices of the $[\mathrm{Si}, \mathrm{Al}]-[\mathrm{O}$, $\mathrm{N}]$ network, but $\beta$-sialon does not contain the "stabilizing" cations. Sialon ceramics are promising candidates for engineering applications because of their excellent hardness, wear resistance and corrosion resistance at room and high temperatures. However, the toughness of the material is low ( $\alpha$-sialon: 3-5 $\mathrm{MPa} \mathrm{m}^{1 / 2}$ and $\beta$-sialon: 5-7 $\mathrm{MPa} \mathrm{m}^{1 / 2}$ ) and densification requires high temperatures (normally above $1750^{\circ} \mathrm{C}$ ), which limit their wide applications as structural components.

\footnotetext{
* Corresponding author. Tel.: +61 3 99054930; fax: +61 399054940.

E-mail address: yibing.cheng@ spme.monash.edu.au (Y.-B. Cheng).
}

To improve the toughness of sialons, many attempts have been made to adjust the microstructure and grain morphology. The bimodal microstructures containing large elongated grains in a fine and uniform matrix have shown obvious advantages in toughening because of crack deflection and crack bridging mechanisms introduced by the large elongated grains. ${ }^{4,5}$ However, the sintering temperature of the material is still very high and the toughness may not improve if the grain boundary is strongly bonded. ${ }^{6}$ Another toughening approach used metal additions to enhance the toughness of sialons, similar to what were achieved in $\mathrm{Al}_{2} \mathrm{O}_{3}$ ceramics. ${ }^{7,8}$ Several transition metals, such as $\mathrm{Fe}, \mathrm{Ni}, \mathrm{Cr}, \mathrm{Mn}$, have been used to improve the toughness of sialons and a two-fold increase in the toughness of sialons has been reported. ${ }^{9}$ But in these studies, the transition metals were added into sialon compositions in metallic powder forms. Several difficulties are encountered when metallic powder is used in processing of sialon-transition metal composites. Due to the flammability of fine metallic powders, the size of metallic particles is usually above $1 \mu \mathrm{m}$. At high temperature, the metallic phase aggregated easily and the size of the metallic inclusions in composites usually becomes far too large. The large size inho- 
mogeneity could generate microcracks due to thermal expansion mismatch between the metal and ceramic phases. Furthermore, $\mathrm{Si}_{3} \mathrm{~N}_{4}$ is very reactive to many transition metals ${ }^{9-11}$ directly to form metallic silicides and generate gas phases. These reactions usually take place before the densification of the composite systems, so fully dense composites are thus difficult to be achieved.

In the present study, transition metal oxides, instead of transition metals, are used in the starting compositions. Because of the transient liquid phase sintering mechanism for sialon ceramics, it may be possible to form a uniform transient liquid phase containing metal oxides at the sialon grain boundaries when sintering temperature is above the eutectic of the system, from which metallic phases may precipitate at a higher temperature by reduction in graphite furnace. In this case, the metal oxides in the starting powders would not only provide the metallic phases in final composites, but also play an important role to assist sintering. To validate these assumptions, three aspects are explored in the present study: (1) the possibility to stable $\alpha$-sialon using transition metals; (2) the possibility to obtain sialon-transition metal silicides composites with a uniform microstructure; and (3) the possibility to toughen $\alpha$-sialon ceramics by metallic silicides.

\section{Experimental}

The compositions of the starting materials, $\alpha-\mathrm{Si}_{3} \mathrm{~N}_{4}$ (M11, Stark, Germany), AlN (AT, Stark, Germany), $\mathrm{Al}_{2} \mathrm{O}_{3}$ (99.9\%, AJAX, Australia) and $\mathrm{Cr}_{2} \mathrm{O}_{3}$ (99\%, BDH, England) or $\mathrm{Fe}_{2} \mathrm{O}_{3}$ (99\%, BDH, England) are shown in Table 1. Compositions of metal oxides are designed to form $\alpha$-sialon phases according to a nominal $\alpha$-sialon composition $(m=1, n=1.7)$. An extra amount of transition metal oxide was added as an additive for the metal source. The starting powders were ball milled in isopropanol for $24 \mathrm{~h}$ and, then dried and pressed uniaxially into cylinders in a diameter of $25 \mathrm{~mm}$. Hot-pressing (HP) and pressure-less sintering (PLS) were carried out in a graphite furnace with a flowing $\mathrm{N}_{2}$. The heating rate was $30^{\circ} \mathrm{C} / \mathrm{min}$ and after sintering, the specimens were cooled down with the natural cooling rate in the furnace. Some samples embedded in graphite powder were further heat-treated in a tube furnace in a nitrogen atmosphere at $1300^{\circ} \mathrm{C}$ for $6 \mathrm{~h}$.

The density of the specimens was measured according to the Archimedes principle. Phase characterization was

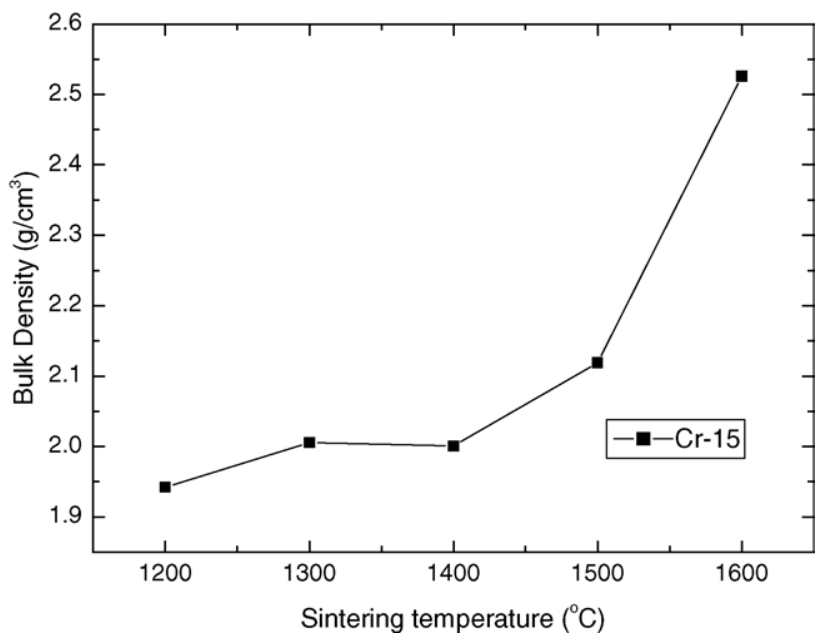

Fig. 1. Densification curve for Cr-15 specimens hot-pressed at different temperatures for $1 \mathrm{~min}$.

performed using X-ray diffraction method (XRD, Rigaku Geigerflex Diffractometer, Rigaku Co., Japan). The sintered samples were ground and polished with diamond paste. The microstructures were examined using back-scattered image model of scanning electron microscopy (SEM, JEOL JSM 840A). The composition of each phase was determined with an energy dispersive spectrometer. The volume fraction of the metallic phase in the fired composites was measured with a point counting technique from the SEM micrographs.

\section{Results and discussion}

\subsection{Preparation of sialon-Cr-silicide composites}

In order to observe the densification and reaction sequence of the composites, sample $\mathrm{Cr}-15$ was hot-pressed in the graphite furnace at $1200,1300,1400,1500,1600^{\circ} \mathrm{C}$ for $1 \mathrm{~min}$ and $1600^{\circ} \mathrm{C}$ for $1 \mathrm{~h}$, respectively. The densification curve and phase evolution for the composites are shown in Figs. 1 and 2, respectively. The density of the composites remains low after the first appearance of some metallic silicides at $1400^{\circ} \mathrm{C}$. Densification starts to pick up as the hot-pressing temperature rises to $1500^{\circ} \mathrm{C}$.

As shown in Fig. 2, $\mathrm{Cr}_{2} \mathrm{O}_{3}$ disappeared and $\mathrm{CrSi}_{2}$ formed after heating to $1300^{\circ} \mathrm{C}$. As temperature increased, the

Table 1

Compositions used to prepare sialon-metal silicide composites

\begin{tabular}{lllllll}
\hline Samples & Nominal phases & \multicolumn{3}{l}{$\alpha$-Sialon $(m=1, n=1.7)($ wt. $\%)$} & & \multirow{2}{*}{ Extra $\mathrm{M}_{2} \mathrm{O}_{3}($ wt. \%) } \\
\cline { 3 - 6 } & & $\mathrm{Si}_{3} \mathrm{~N}_{4}$ & $\mathrm{AlN}$ & $\mathrm{Al}_{2} \mathrm{O}_{3}$ & $\mathrm{M}_{2} \mathrm{O}_{3}$ & \\
\hline $\mathrm{Cr}-3$ & $\mathrm{Cr}-\alpha$-sialon $+3 \% \mathrm{Cr}_{2} \mathrm{O}_{3}$ & 75.8 & 16.62 & 3.24 & $4.34^{\mathrm{a}}$ & $3^{\mathrm{a}}$ \\
$\mathrm{Fe}-3$ & $\mathrm{Cr}-\alpha$-sialon $+3 \% \mathrm{Fe}_{2} \mathrm{O}_{3}$ & 75.51 & 16.55 & 3.23 & $4.71^{\mathrm{b}}$ & $3^{\mathrm{b}}$ \\
$\mathrm{Cr}-15$ & $\mathrm{Cr}-\alpha$-sialon $+15 \% \mathrm{Cr}_{2} \mathrm{O}_{3}$ & 75.8 & 16.62 & 3.24 & $4.34^{\mathrm{a}}$ & $15^{\mathrm{a}}$ \\
$\mathrm{Fe}-15$ & $\mathrm{Cr}-\alpha$-sialon $+15 \% \mathrm{Fe}_{2} \mathrm{O}_{3}$ & 75.51 & 16.55 & 3.23 & $4.71^{\mathrm{b}}$ & $15^{\mathrm{b}}$ \\
\hline
\end{tabular}

\footnotetext{
${ }^{\mathrm{a}} \mathrm{Cr}_{2} \mathrm{O}_{3}$.

${ }^{b} \mathrm{Fe}_{2} \mathrm{O}_{3}$.
} 


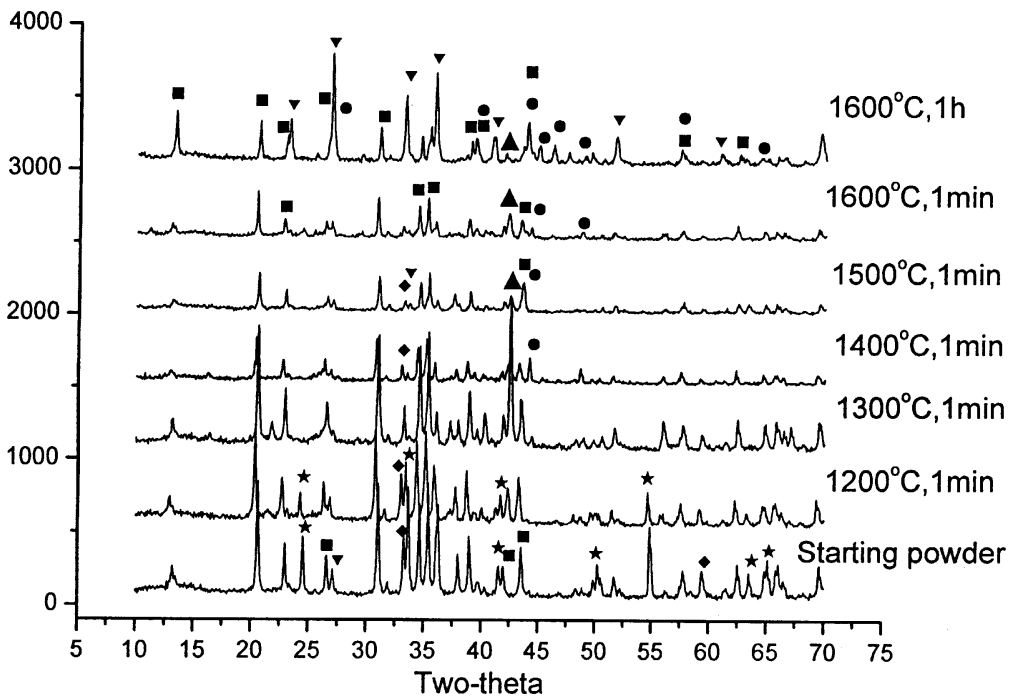

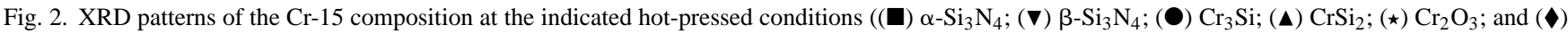
AlN).

amount of $\mathrm{CrSi}_{2}$ decreased and a high-temperature silicide, $\mathrm{Cr}_{3} \mathrm{Si}$ was then formed. The oxygen partial pressure in the graphite die can be as low as $10^{-15} \mathrm{~atm}$ at $1600^{\circ} \mathrm{C} .{ }^{11}$ Under this condition, $\mathrm{Cr}_{2} \mathrm{O}_{3}$ in the sample can be reduced to produce $\mathrm{Cr}$ metal. The presence of silicon nitride may further accelerate the reduction of $\mathrm{Cr}_{2} \mathrm{O}_{3}$. However, no $\mathrm{Cr}$ is detected in the sample fired at all temperatures studied, indicating that as soon as $\mathrm{Cr}$ was formed from the reduction of $\mathrm{Cr}_{2} \mathrm{O}_{3}$, it reacted with silicon nitride to form silicide following the reaction,

$\mathrm{Si}_{3} \mathrm{~N}_{4}+1.5 \mathrm{Cr}=1.5 \mathrm{CrSi}_{2}+2 \mathrm{~N}_{2}$

The lowest eutectic temperature in the $\mathrm{Cr}-\mathrm{Si}$ binary alloy system is $1305^{\circ} \mathrm{C} .{ }^{12}$ This eutectic is formed between $\mathrm{Si}$ (with the solution of $10 \mathrm{ppm} \mathrm{Cr}$ ) and $\mathrm{CrSi}_{2}$. From the binary phase diagram of the $\mathrm{Cr}$ and $\mathrm{Si}$ system, ${ }^{13}$ a series of $\mathrm{Cr}-\mathrm{Si}$ compounds can be formed, following a phase transition sequence from $\mathrm{CrSi}_{2}, \mathrm{CrSi}, \mathrm{Cr}_{5} \mathrm{Si}_{3}$ to $\mathrm{Cr}_{3} \mathrm{Si}$ with the increase of $\mathrm{Cr}$ content. The $\mathrm{Cr}_{3} \mathrm{Si}$-silicide phase has the highest melting point, $1770{ }^{\circ} \mathrm{C}$ among all $\mathrm{Cr}$-silicides. Thus, the final product obtained at $1600^{\circ} \mathrm{C}$ containing a very refractory $\mathrm{Cr}$-silicide phase.

The main phases in the composition Cr-15 after hotpressing at $1600^{\circ} \mathrm{C}$ for $1 \mathrm{~h}$ are $\beta$-sialon and $\mathrm{Cr}_{3} \mathrm{Si}$. A small amount of $\alpha-\mathrm{Si}_{3} \mathrm{~N}_{4}$ also exists, but no $\alpha$-sialon is detected. If $\mathrm{Cr}_{2} \mathrm{O}_{3}$ was replaced by $\mathrm{Me}_{2} \mathrm{O}_{3}$ (e.g. $\mathrm{Me}=\mathrm{Yb}$ ) and other compositions kept the same as that in sample $\mathrm{Cr}-15, \alpha-$ sialon should have been the major phase after fired at this temperature. ${ }^{14}$ The result suggests that transition metal ion $\mathrm{Cr}$ is not an effective stabilizer for the $\alpha$-sialon structure. The ionic radii of $\mathrm{Cr}^{3+}$ and $\mathrm{Cr}^{2+}$ are 0.63 and $0.89 \AA$, respectively. The ionic size of $\mathrm{Cr}^{2+}$ is similar to that of $\mathrm{Yb}^{3+}$ $(0.858 \AA)$ and $\mathrm{Cr}^{3+}$ similar to $\mathrm{Mg}^{2+}(0.66 \AA)$. Both $\mathrm{Yb}^{3+}$ and $\mathrm{Mg}^{2+}$ are good $\alpha$-sialon stabilizers. ${ }^{3}$ Thus, the ionic radius appears not to be a critical factor for $\alpha$-sialon stabilization. The formation temperature $\left(1300^{\circ} \mathrm{C}\right)$ of $\mathrm{Cr}$-silicide is lower than that for $\alpha$-sialon $\left(>1500{ }^{\circ} \mathrm{C}^{14}\right)$. Once the $\mathrm{Cr}$-silicide phase is formed, it may prohibite chromium from entering the $\alpha$ sialon structure. As a result, the solubility of transition metal ion in $\alpha$-sialon may be too low to form a stable $\alpha$-sialon phase.

Microstructural features of the sialon-Cr-silicide system at different temperatures are shown in Fig. 3. A typical micrograph of the composite after hot-pressed at $1600^{\circ} \mathrm{C}$ for $1 \mathrm{~h}$ is also shown in the figure. EDS results confirm that the bright particles in the back scattered SEM images are Cr-silicide which is in the range of $200-300 \mathrm{~nm}$ in size when sintered at 1300 and $1400^{\circ} \mathrm{C}$. This particle size is much smaller than that of the starting $\mathrm{Cr}_{2} \mathrm{O}_{3}$ powder, which was in the range of several micrometers, suggesting that the $\mathrm{Cr}$-silicide particles resulted from a process of solution and precipitation. It is thought that the added $\mathrm{Cr}_{2} \mathrm{O}_{3}$ dissolved in a transient liquid phase below $1300^{\circ} \mathrm{C}$, and then $\mathrm{Cr}$ metal precipitated from the liquid due to the reducing environment and reacted with the surrounding silicon nitride to form chromium silicide when temperature further increased. On the other hand, the transient liquid phase could also facilitate the mass transportation and assist densification. Grain growth of the $\mathrm{Cr}$-silicide phase appears not significant when sample $\mathrm{Cr}-15$ was fired between 1400 and $1600{ }^{\circ} \mathrm{C}$ for $1 \mathrm{~min}$ only. But the $\mathrm{Cr}$-silicide phase underwent considerable coarsening after heating for $1 \mathrm{~h}$ at $1600^{\circ} \mathrm{C}$.

The microstructures of $\mathrm{Cr}-\alpha$-sialon compositions containing extra 3 and 15 wt. $\% \mathrm{Cr}_{2} \mathrm{O}_{3}(\mathrm{Cr}-3$ and $\mathrm{Cr}-15)$ hot-pressed at $1600^{\circ} \mathrm{C}$ for $1 \mathrm{~h}$ are shown in Fig. 4 . As indicated, the Crsilicide particles distributed uniformly within the sialon matrix in both compositions. The microstructures of Cr-3 and $\mathrm{Cr}-15$ are very similar except the difference in the volume and particle size of the metal silicide. In sample $\mathrm{Cr}-3$, the silicide phase is about 4 vol. $\%$ and the average particle size around $1 \mu \mathrm{m}$. In sample $\mathrm{Cr}-15$, the silicide is about 12 vol.\% 

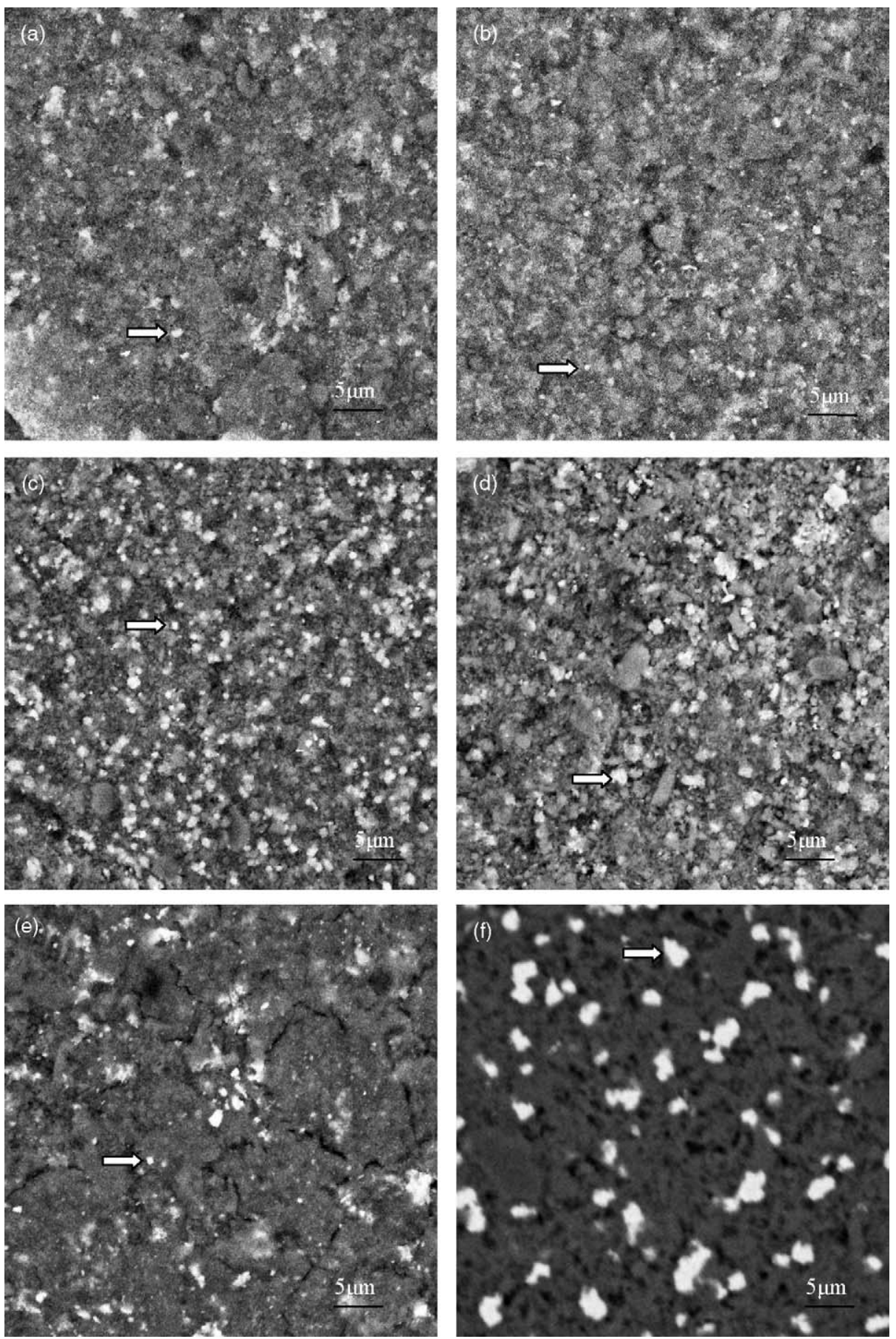

Fig. 3. Back scattered SEM microstructures for sample Cr-15 hot-pressed at (a) $1200{ }^{\circ} \mathrm{C}$; (b) $1300^{\circ} \mathrm{C}$; (c) $1400{ }^{\circ} \mathrm{C}$; (d) $1500^{\circ} \mathrm{C}$; (e) $1600^{\circ} \mathrm{C}$ for $1 \mathrm{~min}$ and (f) $1600^{\circ} \mathrm{C}$ for $1 \mathrm{~h}$. Some $\mathrm{Cr}$-silicide particles are indicated with arrows.

and the average particle size around $2.5 \mu \mathrm{m}$. A significant increase in apparent density is noted for the increase of $\mathrm{Cr}_{2} \mathrm{O}_{3}$ content in the samples from $3 \mathrm{wt} . \%\left(\rho_{\mathrm{Cr}-3}=2.12 \mathrm{~g} / \mathrm{cm}^{3}\right)$ to $15 \mathrm{wt} . \%\left(\rho_{\mathrm{Cr}-15}=2.90 \mathrm{~g} / \mathrm{cm}^{3}\right)$. A denser microstructure can also be found for sample Cr-15 compared to Cr-3 (Fig. 4). It indicates that the introduction of chromium oxide has assisted densification of sialon-silicide composites through the formation of more liquid in the system.

\subsection{Preparation of sialon-Fe-silicide composites}

The phase and microstructure evolution of sialon-Fesilicide composites are very similar to those of the sialon-Crsilicide composites. As demonstrated in Fig. 5, the disappearance of $\mathrm{Fe}_{2} \mathrm{O}_{3}$ took place at $1200^{\circ} \mathrm{C}$, which is about $100^{\circ} \mathrm{C}$ lower than the disappearance of $\mathrm{Cr}_{2} \mathrm{O}_{3}$. There was no metallic $\mathrm{Fe}$ phase detected in the sample when sintering temperature 

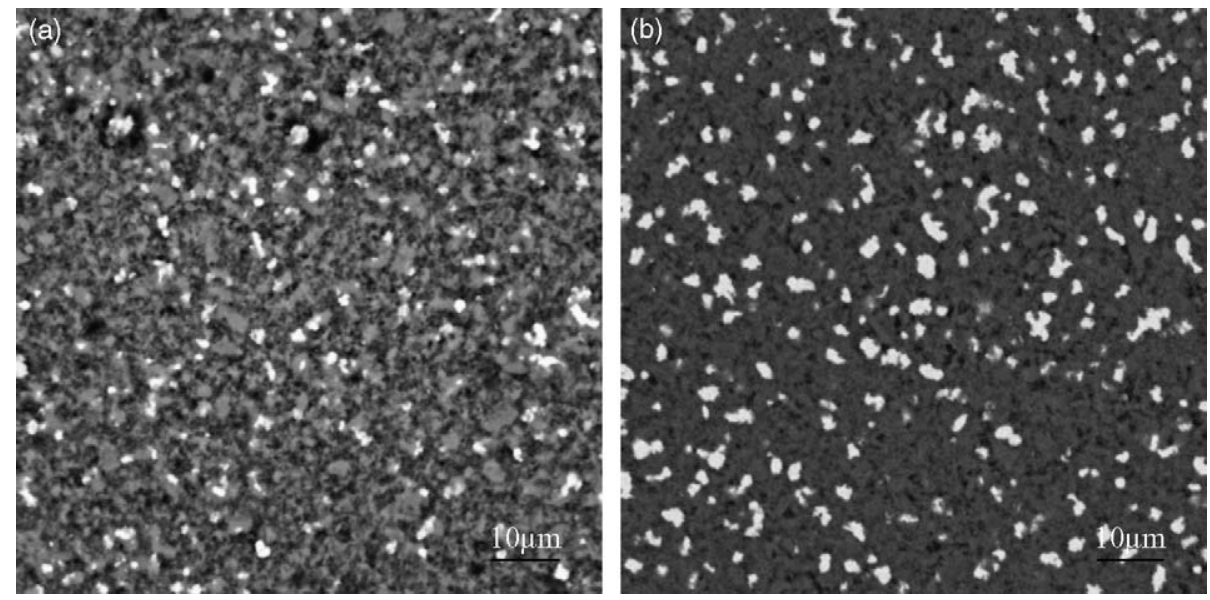

Fig. 4. Backscattered electron images of samples (a) $\mathrm{Cr}-3$ and (b) $\mathrm{Cr}-15$ hot-pressed at $1600^{\circ} \mathrm{C}$ for $1 \mathrm{~h}$.

further increased. The resulting phases after fired at $1600^{\circ} \mathrm{C}$ were $\alpha-\mathrm{Si}_{3} \mathrm{~N}_{4}, \beta$-sialon, $\mathrm{FeSi}$ and $\mathrm{Fe}_{5} \mathrm{Si}_{3}$. The microstructure of the sialon-Fe-silicide composite (as shown in Fig. 6) is very similar to that of sialon-Cr-silicide composite, except that the Fe-silicide particles are smaller in size. The similarity of the two systems suggests that the design concept of the present study may be applicable to other sialon-transition metal silicide systems.

\subsection{Effect of post-sintering heat-treatment}

The microstructure of the sialon-Cr-silicide composite (Cr-3) prepared by pressureless sintering at $1600^{\circ} \mathrm{C}$ for $2 \mathrm{~h}$ is shown in Fig. 7. The microstructure of the sintered composite after post-sintering heat-treatment at $1300{ }^{\circ} \mathrm{C}$ for $6 \mathrm{~h}$ is also shown in Fig. 7. After the post-sintering heat-treatment, fiber-like particles with bright contrast were observed within

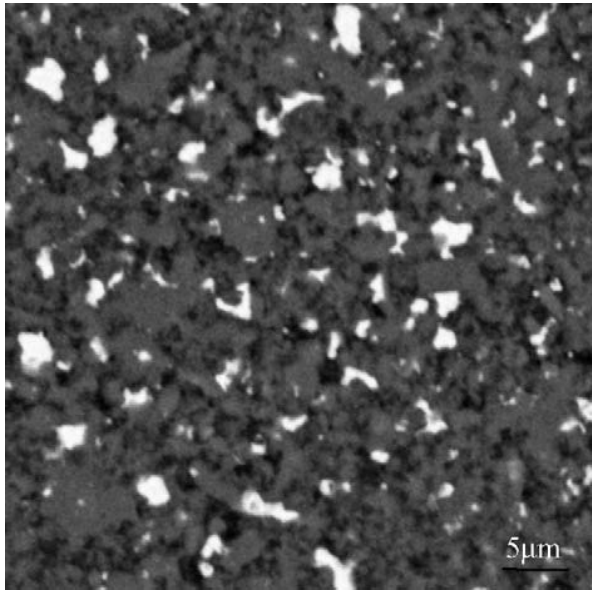

Fig. 6. A typical microstructure of sample Fe-15 hot-pressed at $1600^{\circ} \mathrm{C}$ for $1 \mathrm{~h}$

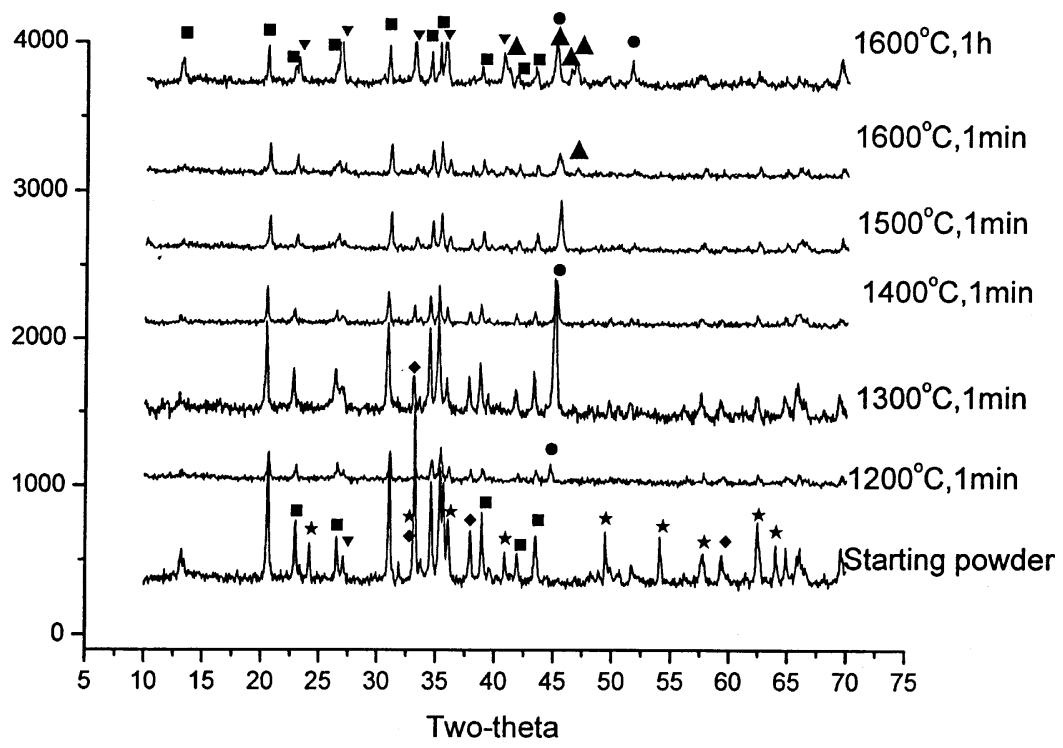

Fig. 5. XRD patterns of the Fe-15 composition at the indicated hot-pressed conditions $\left((\mathbf{\square}) \alpha-\mathrm{Si}_{3} \mathrm{~N}_{4} ;(\boldsymbol{\nabla}) \beta-\mathrm{Si}_{3} \mathrm{~N}_{4} ;(\bullet) \mathrm{FeSi} ;(\mathbf{\Delta}) \mathrm{Fe}_{5} \mathrm{Si}_{3} ;(\star) \mathrm{Fe}_{2} \mathrm{O}_{3} ;\right.$ and $(\bullet)$ AlN). 

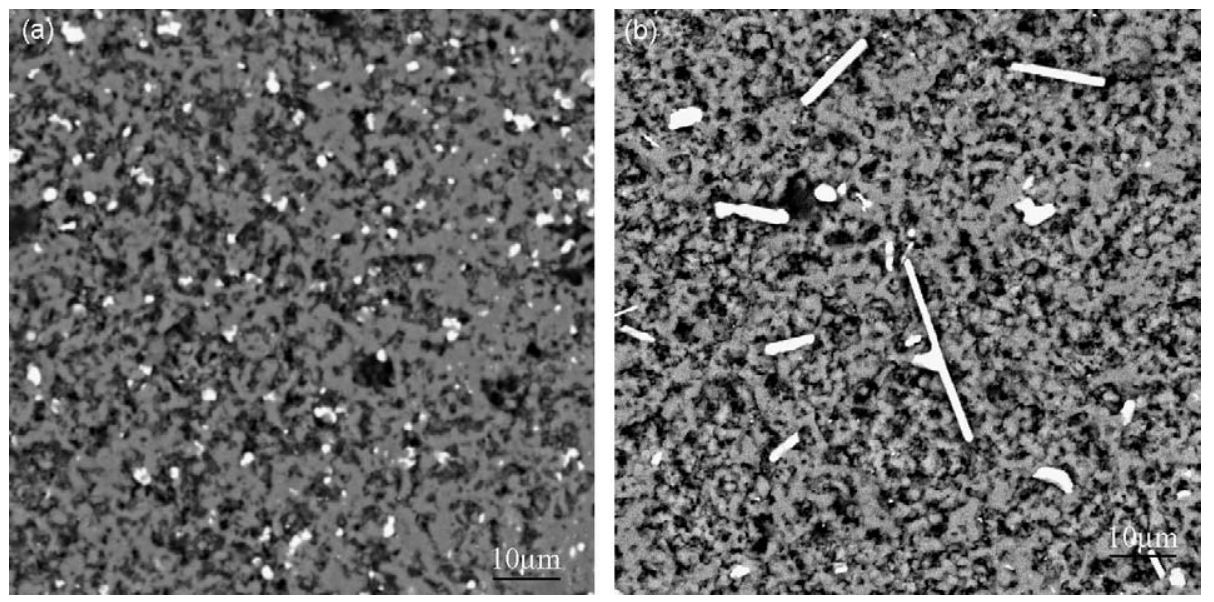

Fig. 7. Backscattered electron images of sample Cr-3 (a) as pressureless-sintered at $1600^{\circ} \mathrm{C}$ for $2 \mathrm{~h}$ and (b) post-sintering heat-treated at $1300^{\circ} \mathrm{C}$ for $6 \mathrm{~h}$.

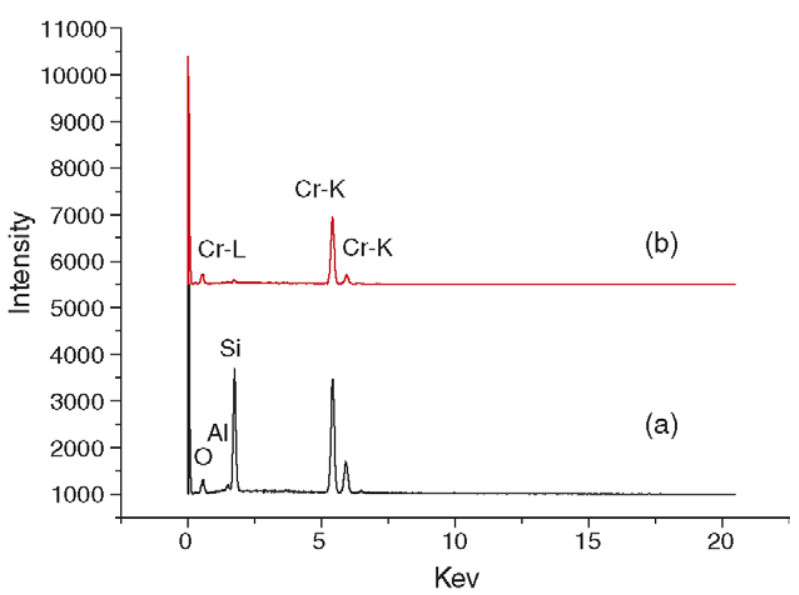

Fig. 8. EDX spectra of (a) the Cr-silicide phase in the pressureless sintered Cr-3 specimen and (b) the fibre-like $\mathrm{Cr}$ phase in the post-sintering heattreated Cr-3 specimen.

a zone of a thickness around 5-10 $\mu \mathrm{m}$ from the surface. Results of EDX analysis on the bright phases in the two samples are shown in Fig. 8. The Cr-silicide particles in the as-sintered sample contain a relatively high concentration of silicon. But the fiber-like phase in the heat-treated sample has a very little $\mathrm{Si}$ content, indicating that the fibers are a metallic Cr phase rather than $\mathrm{Cr}$-silicide. This suggests that silicon may have diffused out of the $\mathrm{Cr}_{3} \mathrm{Si}$ phase during post-sintering heattreatment. Sample Cr-3 has a relatively low density and contains continuous pores. Chromium has a high vapor pressure at $1300^{\circ} \mathrm{C}$, close to $1 \mathrm{~Pa}^{15}$ and thus can evaporate at the heat- treatment temperature. The appearance of the needle shaped $\mathrm{Cr}$ phase may be a result of evaporation of $\mathrm{Cr}$-silicide through continuous pore channels and condensation of metallic $\mathrm{Cr}$ fibers on the sample surface. This phenomenon requires further investigation for an ascertain explanation.

Experimental results of both $\mathrm{Cr}-$ and $\mathrm{Fe}$-sialon systems have demonstrated that transition metals are not effective $\alpha$ sialon stabilizer and they promote the formation of composites containing $\beta$-sialon $(z=1.0)$ and silicides.

\subsection{Mechanical properties}

The mechanical properties of the composites prepared by hot-pressing at $1600^{\circ} \mathrm{C}$ for $2 \mathrm{~h}$ are determined. To facilitate densification, 4 wt. $\% \mathrm{CaO}$ was added in the samples. ${ }^{16}$ The compositions and mechanical performance of the composites are listed in Table 2. Hardness and toughness of these two composites are above $15 \mathrm{GPa}$ and $6 \mathrm{MPa} \mathrm{m}{ }^{1 / 2}$, which are very similar to the normal $\beta$-sialon ceramics. But the samples in the present study were sintered at $1600^{\circ} \mathrm{C}$, much lower than that for $\beta$-sialon (usually around $1750^{\circ} \mathrm{C}$ ). Thus, there is potential for applications of the sialon-silicide composites in structural, refractory and catalyst areas.

Fig. 9 shows the interactions between cracks and metallic silicide particles in both $\mathrm{Cr}$ - and $\mathrm{Fe}$-silicide-sialon systems. Crack deflection and crack bridging due to the presence of the metal silicide are observed (denoted with arrows). The presence of these mechanisms should enhance the toughness of sialons. Nevertheless, the low toughness of the silicide itself

Table 2

Compositions and mechanical properties of $\beta$-sialon $+4 \% \mathrm{CaO}+15 \% \mathrm{M}_{2} \mathrm{O}_{3}$ samples

\begin{tabular}{|c|c|c|c|c|c|c|c|c|}
\hline \multirow[t]{2}{*}{ Samples } & \multicolumn{5}{|c|}{ Compositions (wt.\%) } & \multirow[t]{2}{*}{ Density $\left(\mathrm{g} / \mathrm{cm}^{3}\right)$} & \multirow[t]{2}{*}{$\mathrm{Hv}_{10}(\mathrm{GPa})$} & \multirow[t]{2}{*}{$K_{\mathrm{IC}}\left(\mathrm{MPa} \mathrm{m}^{1 / 2}\right)$} \\
\hline & $\mathrm{Si}_{3} \mathrm{~N}_{4}$ & AlN & $\mathrm{Al}_{2} \mathrm{O}_{3}$ & $\mathrm{CaO}$ & $\mathrm{M}_{2} \mathrm{O}_{3}$ & & & \\
\hline $\mathrm{CrCa}-15$ & 67.06 & 4.07 & 9.87 & 4 & $15^{\mathrm{a}}$ & 3.28 & 15.74 & 6.06 \\
\hline FeCa-15 & 67.06 & 4.07 & 9.87 & 4 & $15^{\mathrm{b}}$ & 3.34 & 15.75 & 6.17 \\
\hline
\end{tabular}

\footnotetext{
${ }^{\text {a }} \mathrm{Cr}_{2} \mathrm{O}_{3}$.

${ }^{\mathrm{b}} \mathrm{Fe}_{2} \mathrm{O}_{3}$.
} 

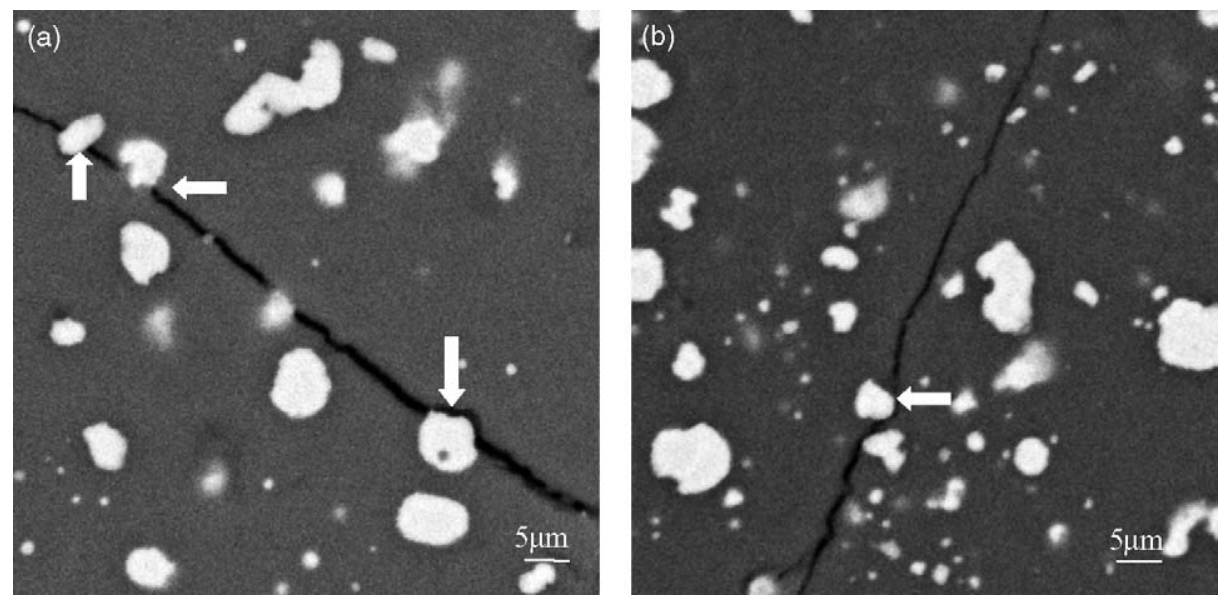

Fig. 9. Bridging silicide particles (indicated with arrows) observed in (a) $\mathrm{CrCa}-15$ and (b) FeCa-15 specimens. The crack was introduced by indentation.

may trade off the benefits induced from the crack bridging. Not many pores are observed in the samples shown in Fig. 9, suggesting that dense sialon-transition metal silicide can be prepared.

\section{Conclusions}

(1) Sialon-transition metal silicides composites with uniform microstructure can be prepared by reaction sintering of silicon nitride and transition metal oxides. A transition oxide-containing liquid forms first, then the transition metal precipitates out with increasing temperature and reacts with surrounding $\mathrm{Si}_{3} \mathrm{~N}_{4}$ to form metal silicides.

(2) Transition metal oxides can be used as sintering aids for sialon ceramics; however, they are not effective stabilizers for $\alpha$-sialon structures.

(3) By applying suitable post-sintering heat-treatment, metallic $\mathrm{Cr}$ fibers can be formed in the surface region of porous sialon body.

(4) Dense sialon-silicide composites can be prepared by adding a small amount of $\mathrm{CaO}$ as a sintering aid.

(5) Typical mechanical properties of dense sialon-silicide composites are $\mathrm{Hv}_{10}>15 \mathrm{GPa}$ and $K_{\mathrm{IC}}>6 \mathrm{MPam}^{1 / 2}$. These values are comparable to those of $\beta$-sialon; nevertheless, the composites can be prepared at a relatively lower sintering temperature than $\beta$-sialon.

\section{References}

1. Jack, K. H., Review: sialons and related nitrogen ceramics. J. Mater. Sci., 1976, 11, 1135-1158.
2. Ekstrom, T. and Nygren, M., Sialon ceramics. J. Am. Ceram. Soc., 1992, 75, 259-276.

3. Cao, G. Z. and Metselaar, R., $\alpha^{\prime}$-Sialon ceramics: a review. Chem. Mater, 1991, 3, 242-252.

4. Becher, P. F., Microstructural design of toughened ceramics. J. Am. Ceram. Soc., 1991, 74, 255-269.

5. Mitomo, M., In-situ microstructural control in engineering ceramics. Key Eng. Mater, 1999, 161-163, 53-58.

6. Sun, E. Y., Becher, P. F. and Hsueh, C. H., Debonding behavior between $\beta-\mathrm{Si}_{3} \mathrm{~N}_{4}$ whiskers and oxynitride glasses with or without an epitaxial $\beta$-sialon interfacial layer. Acta Mater., 1999, 47, 27772785.

7. Ji, Y. and Yeomans, J. A., Processing and mechanical properties of $\mathrm{Al}_{2} \mathrm{O}_{3}-5$ vol.\% $\mathrm{Cr}$ nanocomposities. J. Eur. Ceram. Soc., 2002, 22, $1927-1936$.

8. Chen, R. Z. and Tuan, W. H., Pressureless sintering of $\mathrm{Al}_{2} \mathrm{O}_{3} / \mathrm{Ni}$ nanocomposites. J. Eur. Ceram. Soc., 1999, 19, 463-468.

9. Smith, A. C., Edress, H. J. and Hendry, A., Steel-reinforced sialon matrix composites. Key Eng. Mater., 1992, 72-74, 165-186.

10. Abed, A., Hussain, P. B., Jalham, I. S. and Hendry, A., Joining of sialon ceramics by a stainless steel interlayer. J. Eur. Ceram. Soc., 2001, 21, 2803-2809.

11. Abed, A., Smith, A. C. and Hendry, A., Effect of nitrogen alloying on the densification process of a sialon ceramic-matrix composite containing stainless steel. Mater. Sci. Eng. A: Struct. Mater: Prop. Microstruct. Process., 1995, A202, 218-225.

12. SGTE Substance Data File, Thermodata GmbH, Grenoble University, St. Martin d'Heres, France, 1987.

13. Baker, H., ed., Alloy Phase Diagrams, ASM Handbook, Vol. 3. ASM International, Ohio, USA, 1992.

14. Wang, P. L., Sun, W. Y. and Yan, D. S., Sintering and formation behavior of $\mathrm{R}-\alpha$-sialons $(\mathrm{R}=\mathrm{Nd}, \mathrm{Sm}, \mathrm{Gd}, \mathrm{Er}$ and $\mathrm{Yb})$. Eur. J. Solid State Inorg. Chem., 1994, 31, 93-104.

15. Lide, D. R., ed., CRC Handbook of Chemistry and Physics. (81st ed.) CRC Press, Boca Roton, 2000, pp. 6-66.

16. Hewett, C., Cheng, Y.-B., Muddle, B. C. and Trigg, M. B., Phase relationships and related microstructural observations in the Ca-Si-Al-O-N system. J. Am. Ceram. Soc., 1998, 81, 17811788 